\section{Pacific Northwest}

National Laboratory

Operated by Battelle for the

U.S. Department of Energy

\title{
200 West Area Dust Mitigation Strategies
}

\author{
M. Sackschewsky \\ J. Becker
}

April 2001

Prepared for the U.S. Department of Energy under Contract DE-AC06-76RL01830 


\title{
DISCLAIMER
}

This report was prepared as an account of work sponsored by an agency of the United States Government. Neither the United States Government nor any agency thereof, nor Battelle Memorial Institute, nor any of their employees, makes any warranty, express or implied, or assumes any legal liability or responsibility for the accuracy, completeness, or usefulness of any information, apparatus, product, or process disclosed, or represents that its use would not infringe privately owned rights. Reference herein to any specific commercial product, process, or service by trade name, trademark, manufacturer, or otherwise does not necessarily constitute or imply its endorsement, recommendation, or favoring by the United States Government or any agency thereof, or Battelle Memorial Institute. The views and opinions of authors expressed herein do not necessarily state or reflect those of the United States Government or any agency thereof.

\author{
PACIFIC NORTHWEST NATIONAL LABORATORY \\ operated by \\ BATTELLE \\ for the \\ UNITED STATES DEPARTMENT OF ENERGY \\ under Contract DE-AC06-76RL01830
}

Printed in the United States of America

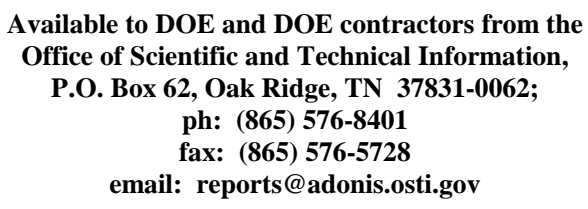

Available to the public from the National Technical Information Service, U.S. Department of Commerce, 5285 Port Royal Rd., Springfield, VA 22161 ph: (800) 553-6847 fax: $(703) 605-6900$

email: orders@ntis.fedworld.gov

online ordering: http://www.ntis.gov/ordering.htm 


\section{WEST AREA DUST MITIGATION STRATEGIES}

PREPARED FOR

CH2M Hill Hanford Group

BY

M.R. SACKSCHEWSKY AND J.M. BECKER PACIFIC NORTHWEST NATIONAL LABORATORY 


\section{WEST AREA DUST MITIGATION STRATEGIES}

\section{Introduction}

Facilities on the west side of the 200 West Area have suffered significant blowing sand and dust related problems as a result of the June / July 2000 Hanford Wildfire. This fire resulted in a completed loss of vegetative cover over an area of at least 10 square miles to the west of the 200 West Area. The fire and subsequent moderate to high wind events soon after the fire initiated a severe blowing sand and dust problem, as well as significantly affecting the soil seed bank (Sarah Baker, unpublished data) within the 200 West expansion area.

Stabilization of the 200W area was attempted by PHMC personnel during the fall of 2000 . Efforts included planting native grasses over most of the expansion area, and protecting the seeding by crimping straw and applying soil stabilizing agents. An approximate 150 yard strip on the east side of the expansion area was planted as a "construction buffer area" using a nonnative mix of crested and thickspike wheatgrasses (Agropyron cristatum and A. daystachyum) and four-wing saltbush (Atriplex canescens).

Overall, the fall 2000 seeding was more successful in the northern portion of the expansion area where she soils are primarily Burbank sandy-loam with lenses of Esquatzel silt loam. The seeding was less successful in the southern portion of the expansion area where the soils are primarily Quincy and Hezel Sands. However, even in the northern portions of the expansion area, it is unlikely that the planted grass will provide significant erosion protection and surface stabilization for at least one more year, and possibly 2 to 3 years.

The PHMC team has initiated work to address the continued sand and dust problems within the $200 \mathrm{~W}$ expansion area. Plans include re-seeding the construction buffer zone and an additional 300 acres in the south west corner of the expansion area. They are also developing an irrigation system to provide water to much of the reseeded area, which will allow the spring seeded grasses to germinate and grow through the summer, and will keep the soil surface moist which should greatly reduce the dust generation within the treated area.

Even with the additional work planned by the PHMC personnel, there are several options that can be pursued by $\mathrm{CHG}$ that may greatly aid in reducing the amount of dust and sand entering the 200W SST facilities in and around MO-281 and 272WA. These options fall within the following general categories:

1) Direct shielding of the facilities

2) Stabilization of the planted areas proximal to the facilities

3) Protecting the planting areas from sand-deposition and small scale sediment control

4) Irrigation to provide dust control and to optimize plant growth

The benefits, costs, and potential problems and disadvantages of options within each of these categories of action are presented in the following sections. Where cost estimates are provided, 
we attempted to determine reasonable market costs for the items or services of interest, and we then tried to err on the conservative, or upper, end of the estimate range. In many of the options presented below, we have considered the application of the action to a reference treatment area in the vicinity of the MO-281 and 272WA (Figure 1). The reference area consists of approximately 50 acres to the northwest, west and south of the MO-281/272-WA facilities. We believe that this area was replanted with a mixture of wheatgrass and a sterile cover crop (winter wheat) on or about 4 April 2001. For facility shielding purposes, we have considered an L-shaped line, approximately $1 / 2$ mile long, extending from south of MO-281 to approximately $1 / 4$ mile north of 272-WA as the reference area location (Figure 1).

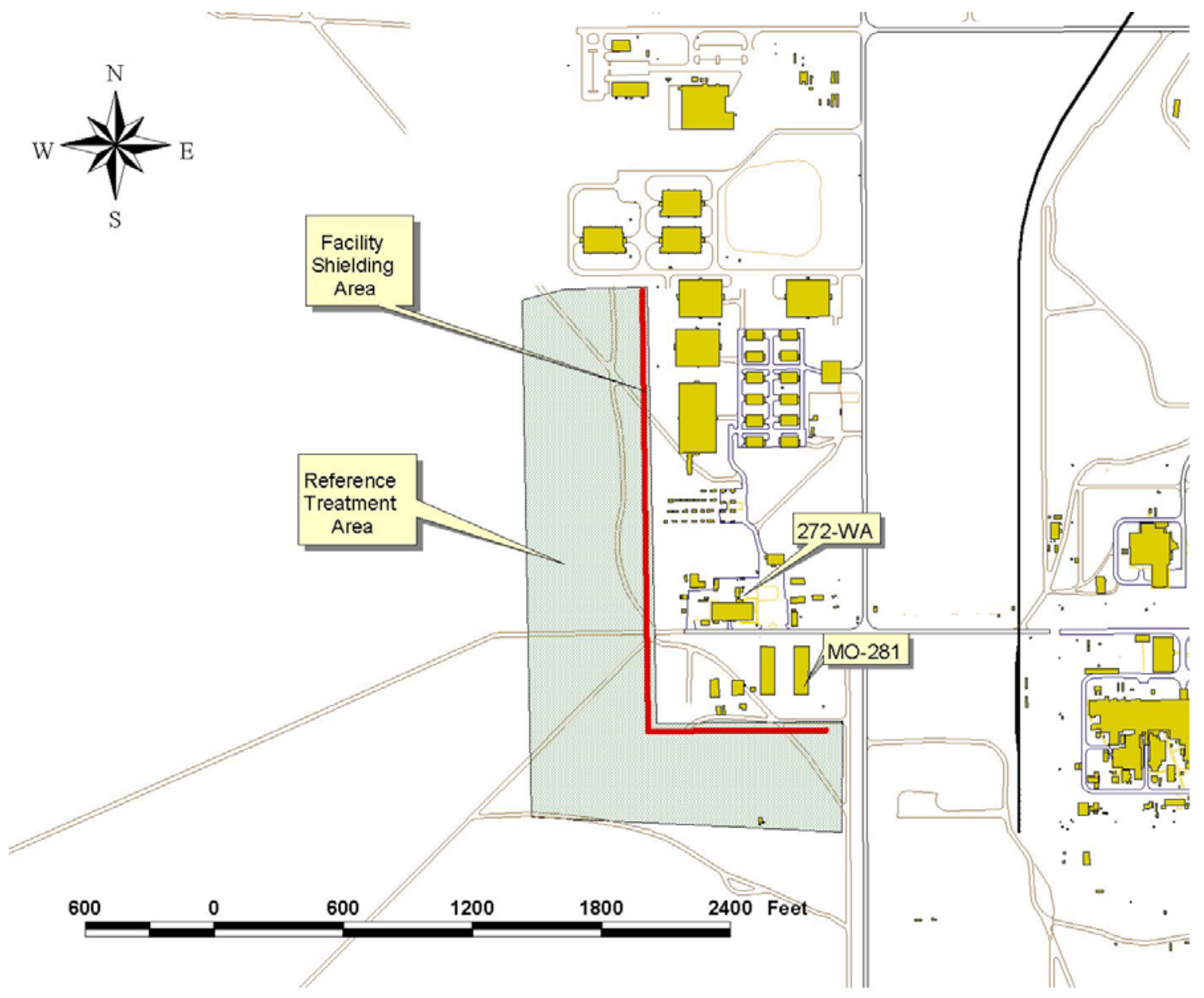

Figure 1. Location of facilities of concern and reference treatment areas.

\section{Facility Shielding Actions}

Two options are available to shield the effected facilities or at least lessen the adverse effects of blowing dust and sand. These options are the installation of a living windbreak using poplars or similar tree species or installation of an artificial windscreen. 


\section{Establishing a Poplar Windbreak}

Poplars are widely used as wind breaks, and could be readily transplanted in the perimeter area of the affected facilities. Two suppliers of poplars were contacted; they are West Winds (Hermiston, Oregon) and Gannon Nurseries (Mabton, Washington). The Mabton supplier was contacted primarily for the purpose of price comparison.

The Hermiston Supplier has two varieties of poplars, 76 and D01, that are potentially useful as windbreaks; these are available in three sizes. Variety 76 is wider and has denser branches than D01, and is thus likely to be more suitable for this application. The following prices apply to both varieties. In-field (as opposed to being in cold storage) poplars 18'-25' tall are currently available for $\$ 12 /$ tree and will remain available at this price until mid-April. During this time, prior to production of new leaves, these trees may be excavated, transported, and transplanted bare root without undergoing water stress. After mid-April (after production of new leaves has begun), upon excavation the roots of these trees would need to be encapsulated in soil and wrapped in burlap prior to transport in order to prevent water stress, doubling the price to $\$ 24 /$ tree. The greater the elapsed time past bud break, the greater the quantity of soil needed to encapsulated the roots, and the harder trees are to handle due to the added weight. For this reason and the associated increase in price, it would be advisable to procure and transplant trees of this size in the fall/winter. Trees of this size would need to be transported in semi trucks at 150-200 trees per load. Based on the number of trees required under the different tree spacing scenarios (Table 1), from two to five semi loads could be required. One semi load would cost $\$ 250-\$ 300$.

The D01 and 76 varieties of trees are also currently available in $7^{\prime}-10^{\prime}$ and $5^{\prime}-7^{\prime}$ sizes. These two sizes are currently available at $\$ 5 /$ tree and $\$ 3 /$ tree, respectively, and are kept in cold storage where the trees remain dormant. Because these trees remain dormant until removal from cold storage, they can be excavated, transported, and transplanted bare root at any time without undergoing water stress. Consequently, there would be no need to double the unit price. The maximum number of $7^{\prime}-10^{\prime}$ or $5^{\prime}-7^{\prime}$ trees that would be needed for the facilities under the tworow spacing scenario (Table 1) could be readily stacked and transported to the Hanford Site in a single truck load for a total cost of $\sim \$ 120$.

Any of the three sizes of these two varieties of trees may be planted in a single row 10'-12' apart. To increase wind protection, these trees may be planted in a single row 6' apart. To maximize wind protection, planting may be done 6' apart in two rows $8^{\prime}$ apart such that trees are offset (staggered). The number of trees and the associated costs required to cover a distance of $1 / 2$ mile surrounding the affected facilities (Figure 1) under these spacing scenarios for the three tree height classes is provided in Table 1. Labor for installation of a double row of 7' - 10' trees is estimated to be approximately $12 \$ \mathrm{~K}$ ([4 people planting 100 trees / day] $=9$ days $* 4$ people $* 8$ $\mathrm{hrs} /$ person/day $* 42 \$ / \mathrm{hr}=12 \$ \mathrm{~K}$ )

The Mabton supplier has three varieties of poplars that are potentially useful as windbreaks; the Siouxland poplar, Noreaster cottonwood, and a hybrid willow (variety Windguard), of which the Windguard is the most preferable for wind protection. These three varieties are available in 8'- 
10 ' stock at a cost of $\$ 9 /$ tree if excavated, transported, and transplanted bare root by mid-April, or $\$ 21 /$ tree if balled and burlapped (after mid-April). These prices are approximately two to four times that of the comparable 7'-10' trees provided by the Hermiston supplier.

Table 1. Poplar costs.

\begin{tabular}{|c|c|c|c|c|c|c|}
\hline \multirow{3}{*}{$\begin{array}{l}\text { Tree } \\
\text { Height } \\
\text { Class }\end{array}$} & \multicolumn{6}{|c|}{ Planting Scenarios } \\
\hline & \multicolumn{2}{|c|}{ Single Row 10'-12' } & \multicolumn{2}{|c|}{ Single Row 6' } & \multicolumn{2}{|c|}{ Two Rows 6' } \\
\hline & No. Trees & Cost $(\$)$ & No. Trees & Cost (\$) & No. Trees & Cost (\$) \\
\hline $\begin{array}{l}18^{\prime}-25^{\prime} \\
\text { Bare Root }\end{array}$ & $220-264$ & $2640-3168$ & 440 & 5280 & 880 & 10560 \\
\hline $\begin{array}{l}18^{\prime}-25^{\prime} \\
\text { Balled and } \\
\text { Burlapped }\end{array}$ & “" & $5280-6336$ & “" & 10560 & “" & 21120 \\
\hline $7^{\prime}-10^{\prime}$ & 66 & $1100-1320$ & “6 & 2200 & “6 & 4400 \\
\hline $5^{\prime}-7^{\prime}$ & “" & $660-792$ & “6 & 1320 & “6 & 2640 \\
\hline
\end{tabular}

For the tree height classes in Table 1, the following general planting, watering, and fertilizing regimen is provided. Trees should be planted at no less than $\sim 100$ ' from the affected facilities and associated parking lots in order to prevent damage from mature trees that could fall over in the future. A backhoe would be required to plant the $18^{\prime}-25^{\prime}$ trees in $3^{\prime}$ x $3^{\prime}$ holes. The smaller two tree sizes could be planted with an auger in 1' x 1' holes. All trees would be watered using a drip-line system.

For maximum growth ( $\geq 7$ ' $/ \mathrm{yr}$ ), the 7'-10' and 5' $-7^{\prime}$ ' trees would require two $2 \mathrm{gal} / \mathrm{hr}$ emitters per tree with each tree receiving $4 \mathrm{gal} / \mathrm{hr}$. The $18^{\prime}-25^{\prime}$ trees would require four $2 \mathrm{gal} / \mathrm{hr}$ emitters $(2$ placed at the base of the trunk and 2 placed 4' on either side) with each tree receiving $8 \mathrm{gal} / \mathrm{hr}$. All tree sizes would be watered 1-1.5 hours each day for the first 6 weeks after planting, and 3-4 times per week thereafter. This would require emplacement of a main irrigation line roughly 1.5 " in diameter parallel to the trees outside the root zone. The main line would carry approximately $100 \mathrm{gal} / \mathrm{min}$ and would subsequently branch into 5 sets each carrying $20 \mathrm{gal} / \mathrm{min}$. Each set would feed to the drip emitters for $1 / 5$ of the total number of trees, and each set would be run sequentially. This system would provide sufficient water pressure to adequately water the maximum number of trees provided in Table 1. Such a system can probably be procured and installed for approximately 5 \$K.

A water-soluble nitrogen fertilizer (e.g., Liquid 32) could be injected into the drip line. Each tree would get $\sim 1 \mathrm{lb}$ nitrogen/yr, requiring a total of $3 \mathrm{lbs}$ of Liquid 32 per tree per year. Liquid 32 is priced at approximately $\$ 0.15 / 1 \mathrm{~b}$, for a total of $\sim \$ 0.50$ per tree per year. Soil samples could be tested at a nominal price by an agronomic laboratory in order to design a more site-specific watering and fertilizing schedule that would produce optimum growth.

Total cost for a $1 / 2$ mile long, double row of $7^{\prime}-10^{\prime}$ trees spaced at 6 ' intervals with $8^{\prime}$ between rows, including trees, planting, irrigation system, and fertilizer is estimated to be approximately 22 \$K. 
It should be noted that transplanting poplars (of any size or variety) to the perimeter of the facilities would likely be only moderately effective at best at shielding buildings and personnel from blowing sand and dust during the summer and fall of CY 2001. Once transplanted, poplars would undergo transplant shock and, in order to recover, would need to become well rooted in the new growth medium. Even under optimal growth conditions (i.e., watering and fertilization), recovery/rooting would likely require from several weeks to several months, and thus limit the amount of above-ground growth and canopy closure that could be attained the first year.

\section{Installation of an Artificial Windscreen}

As discussed above, poplars (of any size or variety) transplanted to the perimeter area of the affected facilities would not provide significant protection or shielding to facilities and personnel from blowing dust and sand during the summer and fall of CY 2001. Construction of a windscreen would likely completely offset the potential lack of effectiveness of the newly transplanted poplars.

Screens typically used for shading (filtering $60 \%$ of sunlight) are also known to be highly effective at reducing wind and wind borne particulates. Consequently, these screens are sometimes used alone or in combination with poplars as windbreaks for orchards. Such screens are made of knitted polypropylene thread and are generally available in two heights, 12' and 20' (Wilson Irrigation Orchard Supply, Yakima, Washington).

The costs for materials to construct a 20 ' or a $12^{\prime}$ 'windscreen $1 / 2$ mile in length would be $\sim \$ 22,000$ and $\sim \$ 16,000$, respectively, including screen, posts (25'and 18', respectively, [all posts 5 "-6" diameter]), and hardware for anchoring the posts. Post spacing is assumed to be at $\sim 16$ ' intervals for both screen heights. Post holes (4' deep for both screen heights) can be pre-drilled using an auger, then it is estimated that $\sim 64$ man-hours would be required to construct $300^{\prime}$ of windscreen (either height), for a total of $\sim 575$ - 600 hours for an entire screen. If a burdened cost of $42 \$ /$ man-hour is assumed, labor would be approximately $25 \$ \mathrm{~K}$ for either screen height. Therefore the total cost is estimated to be approximate 41 to $47 \mathrm{\$ K}$.

Since most blown sand is within $2 \mathrm{~m}$ of the ground surface, a 12' windscreen would likely provide sufficient shielding from particles of this size. Finer particulates (dust) are likely to be suspended at much greater heights, therefore there would be little value added with a 20' windscreen except that it would reduce surface wind velocities for a greater distance (maximum of approximately 250 feet versus approximately 150 feet for the $12^{\prime}$ screen).

Since the screen material contains an ultraviolet ray inhibitor, the estimated windscreen lifespan is 15-20 years; a lifespan of 10 years may be considered certain. No regular maintenance of windscreen material, posts, or anchors is required, except that of occasionally replacing broken parts, etc. Such maintenance activities would require an access road on the leeward side of the screen. Support posts are anchored on the leeward side at $12^{\prime}-15^{\prime}$ from the screen.

Consequently, if a windscreen were to be used in combination with poplars (see below), it would need to be located at least 50' upwind of the trees in order to accommodate both an access road and the support post anchors. 


\section{Evaluation and Comparison of Windscreens and Windbreaks}

Both of these techniques will eventually provide significant shielding for the facilities of concern. A windscreen is likely to be much more effective at shielding facilities and personnel from blowing sand than a windbreak of poplars of a similar height, particularly during the first one to two years after planting. Partial shielding from finer particulates (dust) may be achieved by poplars as they reach sufficient height. However, even under optimal growing conditions (under which poplar starts have been known to attain a height of 60' in 4 years) this would likely require two or more years of growth for 7'-10' poplars planted this spring. Wind screens have the potential to fail during high wind events, which is an obvious disadvantage.

It should be noted that a windscreen would likely facilitate the growth of poplars that otherwise would be subjected to high winds and blowing sand. Exposed poplars would likely not grow as well and require supports to keep them growing upright.

\section{Soil Stabilization Techniques and Establishment of Vegetative Cover}

The area immediately surrounding the MO-281 and 272-WA buildings has been reseeded with an acceptable mixture of non-native species. Because of the harshness of the growing conditions (e.g., loose, sandy soils with virtually no vegetative cover that are subject to high winds), and because the planting was in the spring, both soil stabilization and irrigation are prerequisites to successfully establishing grasses. Seeding recommendations were developed under the work scope for this project, but because the site has already been replanted, they have been attached as an appendix to this document for future reference.

There are usually more options available for soil stabilization if they are considered prior to seeding. Thus, some of the options described below may now be impractical unless we are willing to sacrifice and repeat the reseeding effort. Options considered here include application of soil stabilizing chemicals (such as Soil Sement), application of these chemicals mixed with hydromulch materials, crimped straw, straw blankets, and rock mulches.

\section{Soil Stabilizers}

There are many different products currently marketed for purposes of dust suppression and erosion control. Products include salts, surfactants, polymer emulsions such as Soil Sement, wood bi-products such as ligno-sulfonates, food processing bi-products, and asphalt emulsions. Products that would be suitable for the proposed applications include the polymer emulsions, ligno-sulfonates, and food processing bi-products. All of these classes of compounds will have roughly similar costs, and will have similar disadvantages. They may differ significantly in the length of time that they provide adequate soil stabilization, but without on-site testing with the local soils and climatic conditions it is difficult to determine a priori which class or brand is better for the situation in question. 
Soil Sement, a product of Midwest Industrial Supply, Inc. (Ohio) is a polymer emulsion that is a non-regulated substance (i.e., environmentally safe) and a powerful soil tackifier. Soil Sement has been successfully deployed to control wind erosion at various locations on the Hafnord Site, including contaminated soil (spoil piles) at the SY Tank Farm on the Hanford Site in 1996 (Manuel Aguirre 372-0381). Manufacturers literature and representatives claim that Soil Sement is generally capable of effectively ( $90 \%$ ) controlling dust and erosion, and stabilizing soils 9 months post-treatment.

Soil Sement can be applied simultaneously with mulch, grass seed, and fertilizer using a hydroseeder. In order to ensure sufficient soil aeration and water infiltration to permit grass germination and establishment, Soil Sement would have to be applied at a less-than-optimal rate for long-term soil stabilization. Soil Sement would nonetheless be effective in stabilizing soil, although the duration of that efficacy would be reduced. A simple lab test using soils from the site could be conducted by a local representative (Washington Green and America West Environmental Supplies, Inc. (Pasco, Washington) of the supplier to derive the optimal Soil Sement application rate.

A preliminary estimate of the application rate of Soil Sement would be 62 gal/acre $(\sim 1 \mathrm{gal} / 685$ sq ft), at a cost of $\sim \$ 185 /$ acre. The Soil Sement would be mixed with water at a rate of $\sim 1 / 6$ and would be applied with $1000 \mathrm{lbs}$ mulch/acre, at a cost of \$170/acre. Use of mulch would help ensure adequate soil aeration and water infiltration and provide avenues for germinated seed to grow through Soil Sement. A slow release fertilizer (e.g., 135-60-60) in pelleted form could be applied at $450 \mathrm{lbs} /$ acre in the Soil Sement/mulch mixture, at a cost of $\sim \$ 150 /$ acre. Soil samples could be tested at a nominal price by an agronomic laboratory in order to elucidate a site-specific fertilizer and application rate that would produce optimum grass growth.

The Soil Sement/mulch/fertilizer mixture would be applied using a hydroseeder mounted to a fat-tired floater, a vehicle built such that it would minimize the possibility of becoming stranded in loose sand. According to the representatives we contacted, the cost of an operator, a fat-tired floater, and hydroseeding equipment would be $\sim \$ 430 /$ acre. The total per acre costs for the Soil Sement, mulch, fertilizer, operator, fat-tired floater, and hydroseeding equipment would be $\sim \$ 900-\$ 950$ or about $800 \$$ /acre without the fertilizer, however, this appears to be less than typical bids for hydroseeding / mulching on site - which has run to nearly 2000 \$acre.

For the entire 50 acre reference area the estimated cost of a Soil Sement application is estimated to be at least $31 \mathrm{\$ K}$. If the application includes $1 / 2$ ton of mulch per acre the total cost would be at least 40 \$K.

\section{Evaluation of Soil Stabilizers}

Used correctly, soil stabilizers can provide excellent erosion protection and dust control for relatively long periods of time (up to one year). However, several factors in the present situation are likely to reduce both the efficacy and the length of service for applications of soil sealant. Because the area has been planted, and it is desirable to allow and enhance the grass growth, less product will be applied to the surface, thus reducing the effectiveness and probably the length of service. Additionally, the planned regular irrigation of the area is likely to accelerate the product 
degradation, reducing the length of service. However, the protection provided by a sealant application to the young seedlings could be critical to successful establishment of the grass stand.

Addition of hydromulch would probably increase both the initial effectiveness and the length of service of the application, especially under the regular irrigation conditions that are anticipated.

\section{Straw Crimping}

Most likely the reference area will have straw spread and crimped following the reseeding operations. If this does not occur, it may be the simplest and most inexpensive means of increasing surface roughness, which reduces the rate of surface erosion.

Grass hay typically costs 45 to $75 \$ /$ ton, and is usually applied at a rate of approximately 2 tons per acre. Therefore, the costs for the entire reference area would be approximately $2.5 \$ \mathrm{~K}$ for the straw. Labor and equipment costs for spreading and crimping the straw should be less than $5 \mathrm{\$ K}$ for the entire reference area, for a total cost of approximately $7.5 \$ \mathrm{~K}$ for the 50 acres.

Straw mulches must be applied relatively soon after seeding, otherwise the equipment used for spreading and crimping the materials could damage or kill the sprouting seedlings. Materials are already on hand for this operation, and it is our understanding that straw applications will be applied by the PHMC team during the string 2001 planting.

\section{Straw Blankets}

These blankets are made of natural fibers such as straw, shredded wood or bark, and coconut fibers and are most typically used to control water erosion on steep slopes during intense rain events. For our application, a single layer ( 0.25 "- 0.35 " thick, mesh $5 / 8$ ") straw blanket made of wheat, Sudan grass (beneficial to nitrogen deficient soils, as Sudan grass returns nitrogen to the soil upon decomposition), or a Sudan grass-rice mix would be recommended (Greenfix America, El Centro, California). This type of straw blanket would be placed over the seeded area immediately following planting.

Straw blankets allow sufficient sunlight and water percolation for seed germination and seedling establishment, and act as mulch during decomposition. They have a life expectancy from 10-12 months wherein the blanket is guaranteed to remain intact and retain its original tensile strength. Such straw blankets are available in rolls at a maximum of 8' wide and up to 300' long. It is anchored using staples of various lengths (6"-14") and/or by burying the edges in furrows. The price for this type of straw blanket is $\$ 0.30-\$ 0.32 / \mathrm{yd}^{2}$, with installation an additional $\$ 0.05$ $\$ 0.10 / \mathrm{yd}^{2}$. Total costs for installing a straw blanket over the $\sim 50$ acre reference area (Figure 1) could range from $\$ 84,700$ to $\$ 101,640$.

The main advantage to use of straw blankets is that they will remain effective longer than Soil Sement, if they remain well anchored. Blankets would be more effective in erosion control than crimped straw. Disadvantages include the high relative cost and the potential instability in sandy soils and high winds and the potential to disturb the seeded area if it was necessary to bury the edges in furrows in order to anchor them. Shifting sand and high winds may loosen the 
anchoring system (staples and/or furrows), causing removal of the straw blankets and exposure of the seeded area. If it is necessary to bury edges of the blankets in furrows in order to secure them, burial would undoubtedly disturb the seeded area to a great degree, since the blankets are a maximum of 8 ' wide.

\section{Gravel Mulches}

Gravel mulches can be used to form a barrier to wind erosion of underlying sand, while providing interstitial spaces for grass seedling establishment. They have the added benefit of greatly reducing soil surface evaporation, which creates moist conditions for the growing plants. Gravel mulches can be applied after seeding, although this would greatly disturb the seeded area. A better procedure would be to apply the gravel prior to grass planting, then spread the seed with a hydroseeder. The water used to carry the seed would transport the majority through the interstitial spaces between the gravel to the underlying soil. These interstitial spaces would also allow for establishment and growth of grass seedlings.

Spreading gravel 1 to 2 " deep over the site would require $\sim 150$ yards of gravel per acre. Threequarter inch minus size gravel would cost $\sim \$ 2,524$ /acre for a total of $\sim \$ 126,200$ for the 50 acre area, at a depth of 1 to $2 "$ (based on $\$ 9.75 /$ yd for $<3 / 4$ inch gravel plus delivery from Richland [Central Pre-mix, Pasco, Washington]). This cost would be reduced significantly by obtaining gravel from one or more of the borrow pits proximal to the 200 West Area. Approximately 7500 cubic yards would be required to cover the reference area. Application equipment and labor should be less than $500 \$$ /acre.

The primary advantages of gravel mulches are a high degree of erosion protection, reduced soil evaporation, and unlike Soil Sement and straw blankets, it is certain to remain in place for a long period of time. One potential disadvantage would be an increase in surface temperatures; however, this would be at least partially offset by irrigation. A moderate increase in surface temperatures would not likely hinder the germination and establishment of seeded grasses.

However, this option is probably not available at this time unless the completed seeding effort is sacrificed and the area is re-sown with grass (with a hydroseeder or by broadcasting followed by irrigation) after spreading the gravel mulch.

\section{Protecting the planting areas from sand-deposition and small scale sediment control}

Various techniques are available for sediment control to protect the planted areas by reducing the amount of sediment transported through them. These techniques typically rely on fences or walls to create dunes at selected locations. Single fences or walls provide some benefit, but the effectiveness is usually greatly increased when multiple fences are installed perpendicular to the principle wind direction. Fences or walls are spaced at distances of approximately 13 times the height. Therefore, a series of 4 foot fences can be placed at approximately 50 foot intervals.

Seeded grasses are subject to being buried by blowing sand primarily from the west and westsouthwest (Hoitink et al. 2000). Germination of Siberian wheatgrass, thickspike wheatgrass, and Sherman big bluegrass may be greatly reduced at depths greater than 1 inch (See Appendix). 
Consequently, it is advisable to protect the planted area by placing drift fences or walls upwind to the west and south of the planted area. However, this is likely to be difficult in proximity to MO-281 and 272-WA because the near-in planting will be part of a much larger planting effort and an irrigation system is envisioned that will encompass the entire planted area west of the subject facilities. Drift fences or walls installed to protect the reference area would interfere with the efficient operation of the irrigation system. Longer drift fences or walls could be installed to protect the larger planting area (Figure 2). The planting area protection system shown in Figure 2 would require approximately 6.2 miles of fence or wall material. The reference area would require approximately 2.5 miles of fence or wall material.

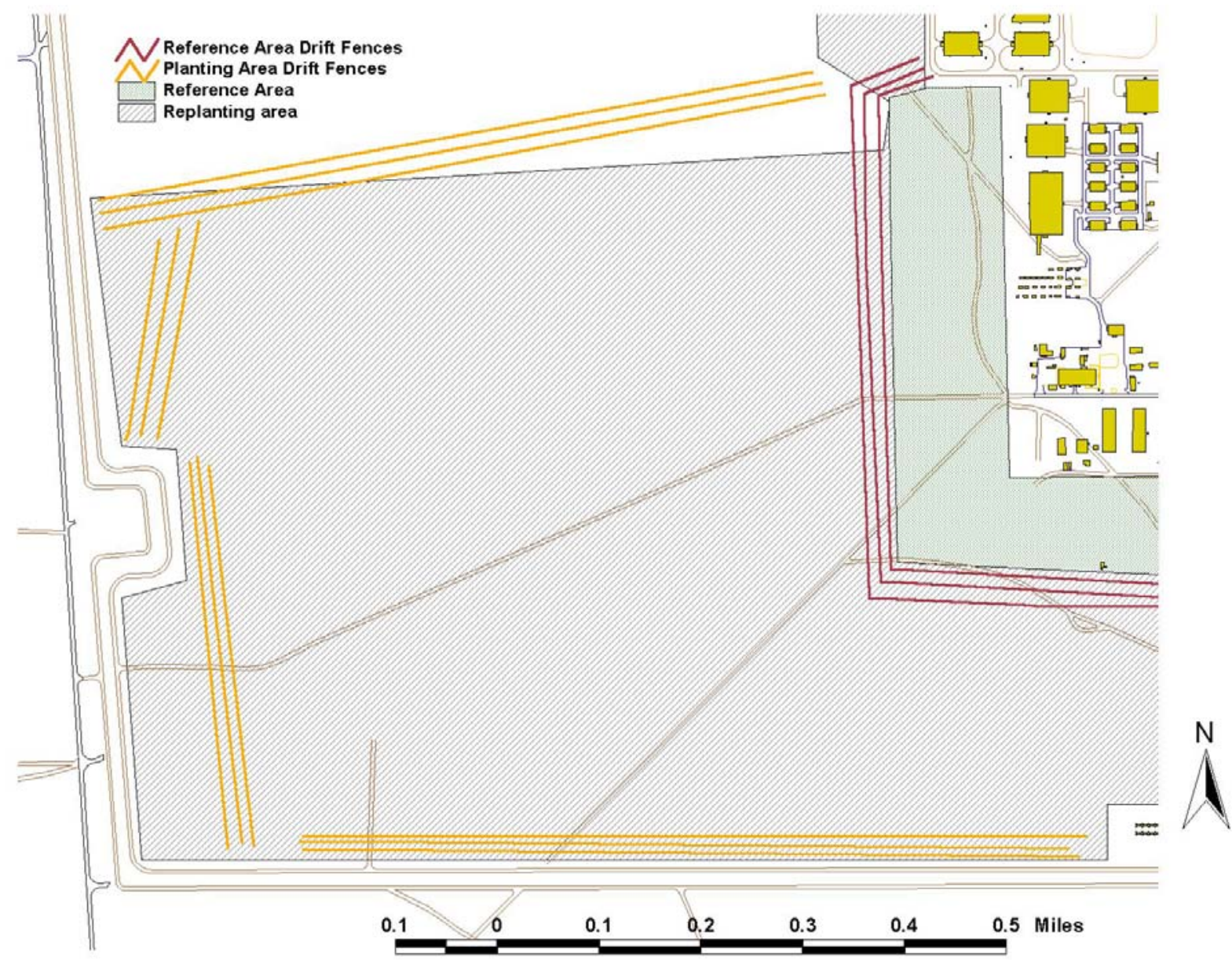

Figure 2. Location of drift fences or walls to protect the Reference and entire planted areas.

Drift Fences. Construction fencing (orange) may be used for this purpose (Stannard M. pers. comm. National Resource Conservation Service, Plant Materials Center [Pullman, Washington]), and is generally available for $\sim \$ 0.35 / \mathrm{ft}$, for a 4 ' height. Enough fencing material for 2.5 miles of mile fences (Figure 2) would cost $\sim 4.6 \$ \mathrm{~K}$. A more suitable finer mesh fencing (the type that is currently just west of 272-WA), 4' high, is available for $\sim \$ 1.77 / \mathrm{ft}$ (Washington Green [Pasco, Washington]). Sufficient fencing material of this type for 2.5 miles of fence would cost $\sim \$ 23.3$ \$K. Fencing above 4' high may not be advisable due to its added propensity for being dislodged by high winds. Steel fence posts (6' high) would be used to anchor 4' fencing material and are 
generally available for $\sim \$ 2.35$. Fence posts should be placed approximately every 20 '. Enough fence posts for 2.5 mile fences would cost $\sim 1.5 \$ \mathrm{~K}$. Fence material would be secured to fence posts using plastic ties. Therefore, total materials would be approximately $6.1 \mathrm{SK}$ for construction fencing and $24.8 \$ \mathrm{~K}$ for specialized drift fencing. Labor for either fence type is estimated to be approximately $8 \$ \mathrm{~K}$.

Baled straw. Baled wheat straw may be used as a substitute for drift fences. Bales (48" long x 18 " wide x 24" high) stacked two-high would provide shielding from blowing sand and dust. Three rows of bales two-high would be spaced at intervals equal to that of drift fences of the same height. Approximately 6600 bales stacked two-high, or 250 tons (based on weight of individual bale $=75 \mathrm{lbs}$.), would be required to cover 2.5 miles of wall at a cost of $11.3 \mathrm{SK}$ (at $\$ 45 /$ ton). Trucking of bales from Basin City (Shannon Zink, provider) to the Hanford Site would cost $\sim \$ 25 /$ ton, for a total of $\sim \$ 6.3 \$ \mathrm{~K}$. Total costs for bales and hauling would be $\sim \$ 17,600$. Labor for installation is estimated to be 17 \$K.

Trade-offs between Drift Fences and Baled Straw. The trade-off between the two types of drift fence and baled straw is dependent on permeability. Impermeable windbreaks (e.g., baled straw) would be most effective at initially decelerating wind (i.e., on the windward side of the windbreak) and retaining windborne particulates. However, air currents on the leeward side of impermeable windbreaks accelerate most rapidly. In contrast, permeable windbreaks (e.g., highway construction site fence) would be least effective at initially decelerating wind and retaining windborne particulates. However, air currents on the leeward side of permeable windbreaks accelerate most slowly. Semi-permeable windbreaks (e.g., the type of drift fence that is currently on the site) fall between permeable and impermeable with respect to these characteristics (Holy 1980).

It should be noted that drift fences would likely be easier to put up than straw bales. However, drift fences and posts would need to be removed after use, whereas straw bales could be left to decompose. A significant disadvantage of fences or walls is that they would have a limited capacity in the volume of sand that would be detained. Once the fences are fully loaded with sand, they must either be moved or the sand deposits must be removed.

If protection of the complete planting area is pursued (i.e. 6.2 miles of fence / wall), it is estimated that material costs would be approximately $15.1 \$ \mathrm{~K}$ for construction fencing (plus est. 21 \$K labor), 57.8 \$K for specialized drift fence, and 43.6 \$K for baled straw (plus est. 40 \$K labor).

Living Fences. The concept of "living fences" pertains to use of shrubs as fences. Shrubs (fourwing saltbush [Atriplex canescens], rubber rabbit brush [Chrysothamnus nauseosus], bitter brush [Purshia tridentate], sagebrush, etc.) may be planted on the leeward side of drift fences and baled straw to provide long-term shielding from blowing sand once fences and straw are no longer effective. This option was not fully evaluated, as the PHMC replanting program includes the planting of sagebrush tubelings over the 300 acre area. 


\section{Irrigation Systems}

Regular applications of water may be the most effective means of controlling dust and sand movement from the areas surrounding MO-281 and 272WA. Water applications result in direct dust control, as well as greatly increase the probability of successful establishment of the planted grass. Irrigation systems can be designed either for the area immediately surrounding the facilities of concern (the 50-acre reference area) or over the larger area that is being planted this spring.

Options evaluated for the 50 acre reference area include above- and below-ground fixed setting systems, water guns, a center pivot, and wheel lines. Options considered for the wider area system include wheel lines and circle systems. All of the options will probably require the installation of a main water line to provide adequate flow and pressure, at a cost of approximately $10 \$ \mathrm{~K}$.

50 Acre - Fixed Setting Systems: Estimates for material and installation of a fixed setting system over the 50 acre reference area are approximately 50 to $75 \$ \mathrm{~K}$ for either an above- or below-ground system. The increased cost of subterranean installation for the below-ground system is offset by the use of less expensive, PVC pipe. However, because the area is now or will soon be planted, below ground installation is probably not a valid option. The above-ground system would require the use of aluminum piping, which could be re-used or re-sold when no longer needed for the present application. Although the initial installation cost of a fixed setting is relatively high, there would be essentially no labor associated with moving lines or sprinklers (it could be completely automated) and the entire area could easily be covered on a daily basis or whatever rotation is needed. This system would be similar to the hand-line system presently at the site - without the need to constantly move the piping to cover the entire area.

50 Acre - Travelling Water Gun: Each water gun costs approximately $30 \$ \mathrm{~K}$ for a gun that . irrigates a circular area $\sim 150$ '-180' in diameter and travels a distance of $1 / 4$ mile along a guide cord. Six 1/2-mile long sections 150'-180' wide would be irrigated in the long arm $(2,600 \mathrm{x}$ 450 ') of the L-shaped area. Six 500' long sections 150'-180' wide would be irrigated in the short arm (900' x 500') of the L-shaped area. Movement of the gun from one section to another would require a tractor. The vehicular traffic required to move the gun between settings would likely be detrimental to the developing grasses. This system would require a substantial labor and equipment investment for continual operations.

50 Acre - Wheel line systems: A wheel line system could be installed for less than 20 \$K if used materials are purchased, the cost of using new materials would be at least $25 \$ \mathrm{~K}$. This system would require significant labor costs to operate. If the width of the reference area is approximately 450 feet, the system would require about seven, 60 foot sections. If the lines can be moved twice a day, each section would be watered once every 3.5 days, if the lines can be moved only once a day each section would be watered once every 7 days (assuming moves on weekends). Two moves per day would probably require essentially full time commitment by two laborers on a daily basis until the end of the summer. We estimate this cost to be at least 50 \$K. Watering each section every 3.5 days may not provide adequate moisture to the developing plants, and it is likely that portions of the soil surface would dry out to the point of dust 
generation between waterings. Both of these concerns would be exacerbated if there were 7 days between waterings. However, either situation may provide the minimum irrigation required for the desired purposes.

50 Acre - Center Pivot: A circle with a radius of 1,300', programmed to irrigate a semi-circle, would cover the long arm (2,600 x 450') of the L-shaped 50 acre area. This circle would cost $\sim \$ 50,000$. The short arm of the L-shaped 50 acre area (900’ x 500' [ 10 acres]) could be irrigated using an above-ground aluminum solid set or buried PVC pipe. Both these systems would cost from $\$ 1,000-\$ 1,500 /$ acre to install, for a total cost of $\$ 10,000-\$ 15,000$. The main line to feed both the circle and either the above-ground aluminum solid set or buried PVC pipe would cost $\sim \$ 7,500(\sim \$ 4.50 / \mathrm{ft}$ over $\sim 1,700$ '). Once the circle and one of these two latter systems was installed, no labor would be required. Thus, the total costs would be $\sim \$ 67,500-\$ 72,500$. There would be minimal labor costs associated with operation of the system, once installed. Additionally, the entire area would be irrigated on a daily basis.

Entire Planting Area - Wheel Line System. The PHMC team has been evaluating a wheel line system that would service an area of approximately 263 acres (Figure 3). This system needs additional analysis, and may not be capable of providing sufficient water to adequately control dust or to enhance grass growth. The original design information indicated that each watering section would be watered once every 11 days, but this figure may be incorrect and the actual rotation may be as much as 24 days. An eleven-day rotation might provide the minimum irrigation requirements, but a 24 day rotation definitely would not. The cost of installing the proposed system will be approximately 50 - $72 \$ \mathrm{~K}$ with similar operational labor requirements as described above for the reference area wheel line system. PHMC estimates that the labor costs would be approximately 72 \$K for operation of the wheel line system until the end of September. Therfore, the overall cost is likely to be between 120 \$k and 150 \$K.

As currently designed, this system would significantly over water ( $\sim$ " per setting) each setting, then each section would be subject to a lengthy drought period.

\section{Whole Planting Area - Circle Irrigation System.}

An alternative irrigation system involves use of three center pivots (circles). The first circle, with a radius of $\sim 1,550$ ', would cover the entire west end of the seeded area (Figure 4), 173.3 acres, and would cost $\sim \$ 55,000$. A second circle, with a radius of $\sim 831$ ', would cover the southeast end of the seeded area (Figure 4), 49.8 acres, and would cost $\sim \$ 30,000$. The third circle, with a radius of $\sim 550$ ', would cover the northeast end of the seeded area (Figure 4), 25 acres, and would cost $\sim \$ 23,000$. Total acreage covered would be $\sim 248$ of the 300 acre seeded area. Total cost for the three circles would be $\sim \$ 108,000$.

The main line (10" diameter) for the center pivot system would run $\sim 3,600$ ' to the largest circle and would cost $\sim 16,000(\sim \$ 4.50 / \mathrm{ft})$. The main line would branch into a 5" line running $\sim 1040$ ' to the medium sized circle at a cost of $\sim \$ 3,000(\sim \$ 2.50 / \mathrm{ft})$, and a 4 " line running $\sim 650$ 'to the small circle for $\sim \$ 1,500(\sim \$ 2.00 / \mathrm{ft})$. Total cost for these three lines would be $\sim \$ 20,000$. 


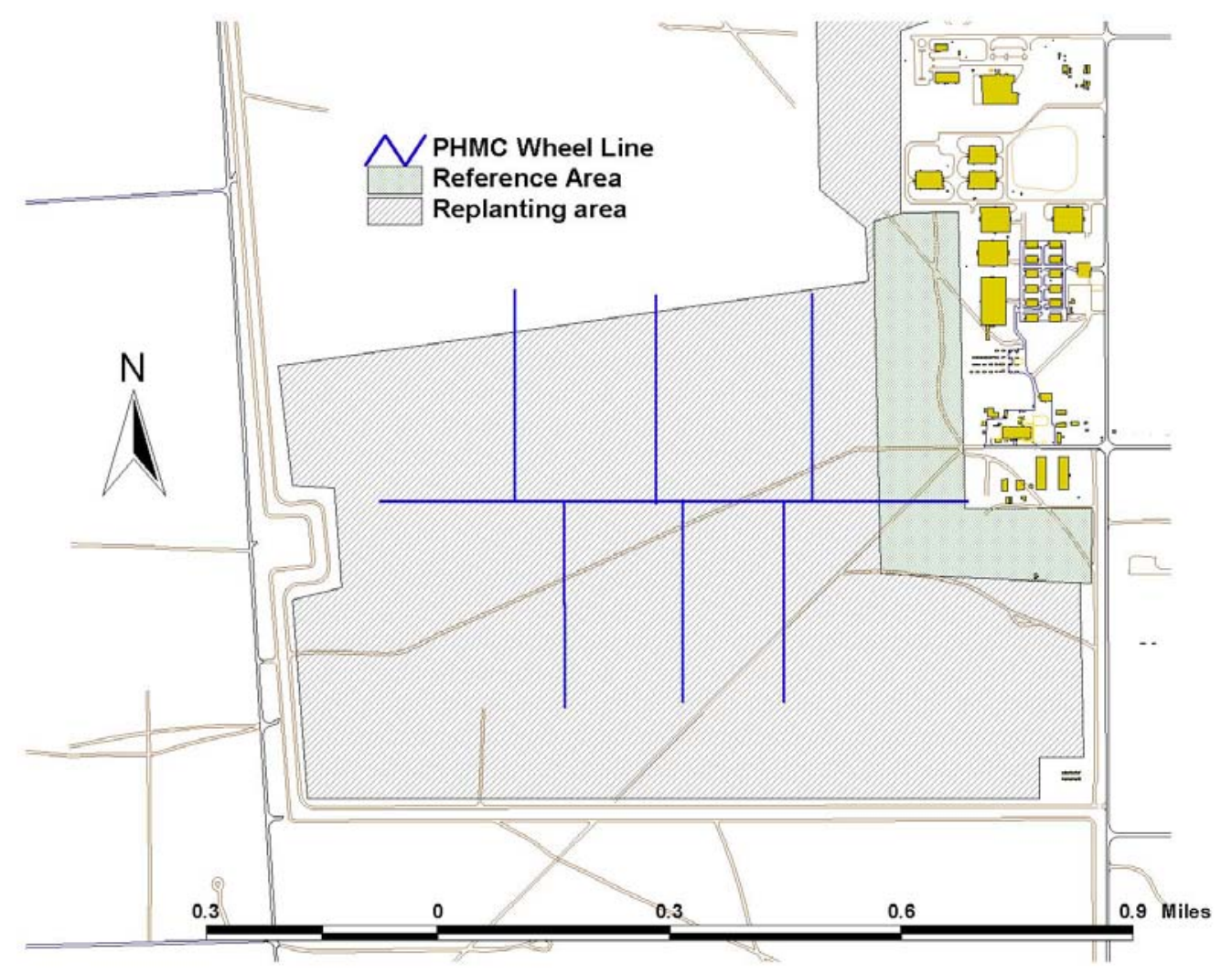

Figure 3. General design of the whole planting area wheel line irrigation system.

The center pivot system would require 460 volt three-phase power. It is estimated that running power lines to the three circles would cost $\sim \$ 20,000$.

Center pivots are completely programmable for speed (allowing variable amounts of water to be delivered over different soil types, etc.), starts/stops, and direction (forward/backward). Once programmed, center pivots run autonomously. Thus, no labor per se would be required.

Consequently, total costs for the center pivot system would be $\sim \$ 148,000$.

A significant advantage of the center-pivot system is that the entire irrigated area will be watered at last once a day, meaning that the entire surface will be wetted - thus suppressing dust, and the soil will be continually moist - aiding the grass establishment. It is currently assumed that $\sim 1,100 \mathrm{gal} / \mathrm{min}$ will be available to irrigate the seeded area. At this rate, a total of 0.25 " per day would be delivered by the center pivot system (based on 248 acres being irrigated in a 24-hour period). 


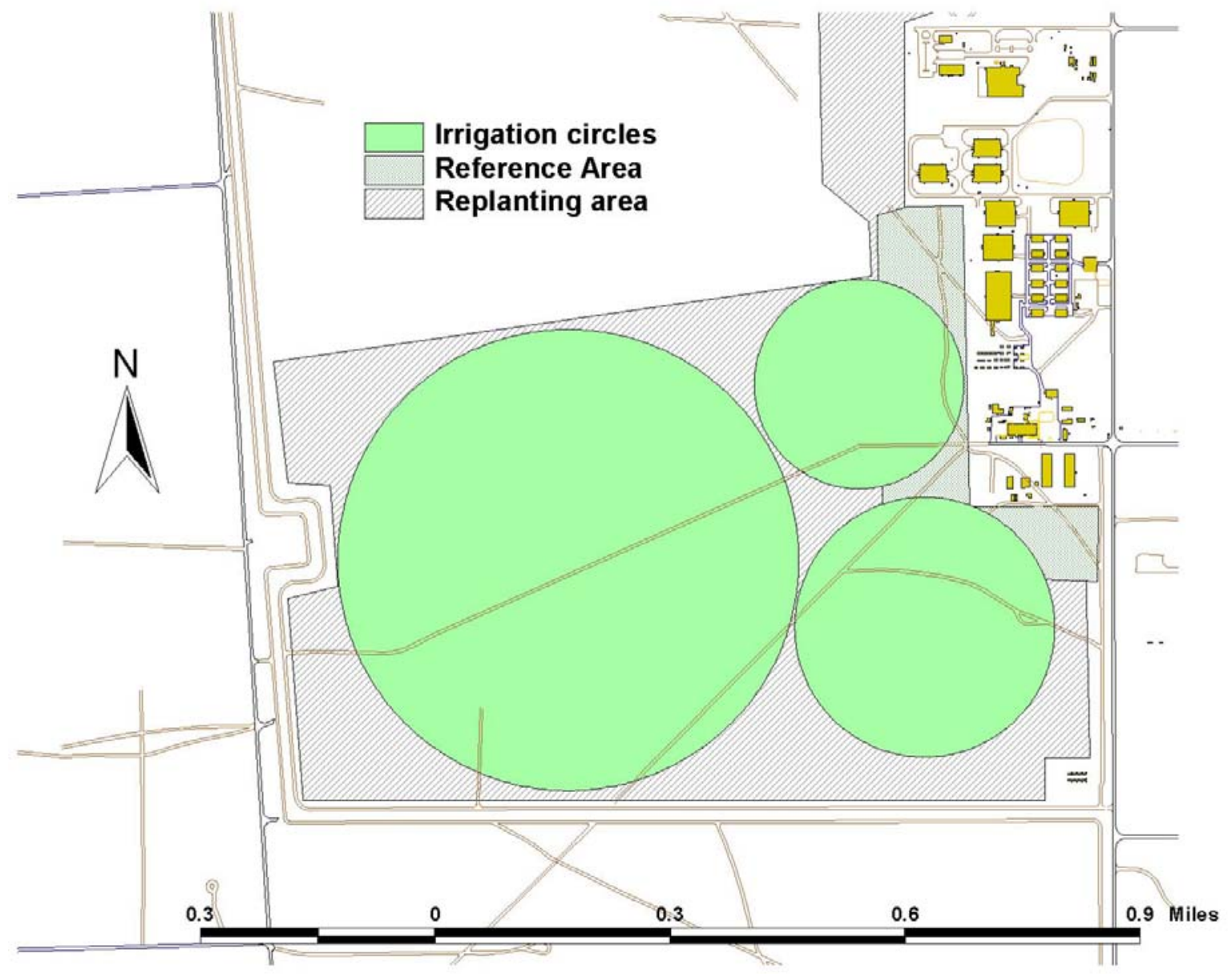

Figure 4. Approximately size and location of irrigation circles. 


\section{Summary of Costs}

Tables 3 and 4 provides a summary of the costs associated with each option described in this document. Many of these options can be combined for a more complete mitigation strategy.

Table 3. Summary of approximate costs for options for shielding facilities and personnel.

\begin{tabular}{|l|c|l|c|c|c|c||}
\hline $\begin{array}{l}\text { Protection } \\
\text { Category }\end{array}$ & Size & Spacing & Quantity & $\begin{array}{c}\text { Unit } \\
\text { Price }\end{array}$ & $\begin{array}{c}\text { Treatment } \\
\text { Dimension/ } \\
\text { Area }\end{array}$ & $\begin{array}{c}\text { Total } \\
\text { Cost }\end{array}$ \\
\hline $\begin{array}{l}\text { Windscreen } \\
\text { (materials) }\end{array}$ & $12^{\prime}$ & ---- & 1 & ---- & $1 / 2$ mile & $\$ 16,000$ \\
\hline $\begin{array}{l}\text { Windscreen } \\
\text { (materials) }\end{array}$ & $20^{\prime}$ & ---- & 1 & ---- & $1 / 2$ mile & $\$ 22,000$ \\
\hline $\begin{array}{l}\text { Windscreen } \\
\text { (labor) }\end{array}$ & $\begin{array}{c}12^{\prime} \text { or } \\
20^{\prime}\end{array}$ & ---- & $600 \mathrm{hrs}$ & $42 \$-$ & $1 / 2$ mile & $\$ 25,000$ \\
\hline Poplars & $5^{\prime}-7^{\prime}$ & $\begin{array}{l}\text { single row } \\
10^{\prime}-12^{\prime}\end{array}$ & $220-264$ & $\$ 3 /$ tree & $1 / 2$ mile & $\$ 660-792$ \\
\hline Poplars & $5^{\prime}-7^{\prime}$ & single row 6' & 440 & $\$ 3 /$ tree & $1 / 2$ mile & $\$ 1,320$ \\
\hline Poplars & $5^{\prime}-7^{\prime}$ & double row 6' & 880 & $\$ 3 /$ tree & 1 mile & $\$ 2,640$ \\
\hline Poplars & $7^{\prime}-10^{\prime}$ & $\begin{array}{l}\text { single row } \\
10^{\prime}-12^{\prime}\end{array}$ & $220-264$ & $\$ 5 /$ tree & $1 / 2$ mile & $\$ 1,100-$ \\
1,320 \\
\hline Poplars & $7^{\prime}-10^{\prime}$ & single row 6 & 440 & $\$ 5 /$ tree & $1 / 2$ mile & $\$ 2,200$ \\
\hline Poplars & $7^{\prime}-10^{\prime}$ & double row 6' & 880 & $\$ 5 /$ tree & 1 mile & $\$ 4,400$ \\
\hline $\begin{array}{l}\text { Poplars } \\
18^{\prime}-25^{\prime}\end{array}$ & $\begin{array}{l}\text { single row } \\
10^{\prime}-12^{\prime}\end{array}$ & $220-264$ & $\$ 24 /$ tree & $1 / 2$ mile & $\$ 5,280-$ \\
\hline Poplars & $18^{\prime}-25^{\prime}$ & single row 6' & 440 & $\$ 24 /$ tree & $1 / 2$ mile & $\$ 10,560$ \\
\hline Poplars & $18^{\prime}-25^{\prime}$ & double row 6' & 880 & $\$ 24 /$ tree & 1 mile & $\$ 21,120$ \\
\hline $\begin{array}{l}\text { Poplar } \\
\text { Installation and } \\
\text { Irrigation }\end{array}$ & & Double Row & 880 & & 1 mile & $\sim \$ 17,000$ \\
\hline
\end{tabular}

\section{Regulatory Considerations}

Most of the mitigation options described in the preceding sections do not have significant regulatory concerns or other impediments to implementation. Any activities that will require surface disturbance or excavations will require cultural and ecological reviews; but much of the area in question was reviewed for the fall 2000 planting activities, and can be readily updated to support new scope. The White Bluffs road requires special protective measures, and at this point it is not clear if an irrigation system that crosses the road would be allowed by the HCRL. If these systems are pursued, the cultural clearance should be evaluated immediately so that the design specifications can include avoidance of this feature.

Some products that have been used for soil stabilization on the Hanford Site have been subsequently banned on site because of concerns about introduction of hazardous materials or because of potential health concerns. It is assumed that if soil fixatives are used, they will have been tested and found to be environmentally acceptable and safe. 
Table 4. Summary of approximate costs for options for soil stabilization and accelerated establishment of selected grasses.

\begin{tabular}{|c|c|c|c|c|c|}
\hline $\begin{array}{l}\text { Protection } \\
\text { Category }\end{array}$ & Size & Quantity & Unit Price & $\begin{array}{c}\text { Treatment } \\
\text { Dimension/ } \\
\text { Area }\end{array}$ & Total Cost \\
\hline Soil Sement & ---- & $62 \mathrm{gal} / \mathrm{acre}$ & $\$ 3 /$ gal & 50 acres & $\$ 9,250$ \\
\hline Hydro Mulch & ---- & $1000 \mathrm{lbs} / \mathrm{acre}$ & $\$ 170 / 1000 \mathrm{lbs}$ & 50 acres & $\$ 8,500$ \\
\hline $\begin{array}{l}\text { Hydromulch } \\
\text { application and } \\
\text { fertlizer }\end{array}$ & & & & 50 acres & $\$ 22,000$ \\
\hline $\begin{array}{l}\text { Irrigation (center pivot } \\
+ \text { above-ground solid } \\
\text { set or buried PVC) }\end{array}$ & ---- & ---- & ---- & 50 acres & $\$ 67,500-\$ 72,500$ \\
\hline $\begin{array}{l}\text { Irrigation (above- } \\
\text { ground solid set or } \\
\text { buried PVC) }\end{array}$ & ---- & ---- & ---- & 50 acres & $\$ 50,000-\$ 75,000$ \\
\hline $\begin{array}{l}\text { Irrigation (traveling } \\
\text { gun [equipment only]) }\end{array}$ & ---- & ---- & ---- & 50 acres & $\$ 40,000$ \\
\hline $\begin{array}{l}\text { Irrigation (wheel-line } \\
\text { equipment + labor) }\end{array}$ & ---- & ---- & ---- & 50 acres & $\$ 80,000$ \\
\hline Irrigation (center pivot) & ---- & ---- & ---- & 248 acres & $\$ 148,000$ \\
\hline $\begin{array}{l}\text { Irrigation (wheel-line + } \\
\text { labor) }\end{array}$ & ---- & ---- & ---- & 263 acres & $\$ 145,000$ \\
\hline $\begin{array}{l}\text { Straw crimping } \\
\text { (material and labor) }\end{array}$ & & & & 50 acres & $\$ 10,000$ \\
\hline $\begin{array}{l}\text { Straw Blanket } \\
\text { (material and labor) }\end{array}$ & $8^{\prime} \times 300^{\prime}$ & ---- & $\$ 0.35-\$ 0.42 / \mathrm{yd}^{2}$ & 50 acres & $\$ 84,700-\$ 101,640$ \\
\hline $\begin{array}{l}\text { Gravel (purchased } \\
\text { Material) }\end{array}$ & $\begin{array}{l}3 / 4 " \\
\text { minus }\end{array}$ & $150 \mathrm{yds} / \mathrm{acre}$ & $\begin{array}{l}\$ 16.83 / y d \\
\text { (delivered) }\end{array}$ & 50 acres & $\$ 126,225$ \\
\hline $\begin{array}{l}\text { Drift Fence } \\
\text { (permeable) (materials } \\
+ \text { labor) }\end{array}$ & 4 ' & 3 rows & $\$ 0.35 / \mathrm{ft}$ & $\begin{array}{l}2.5 \text { mile } \\
6.2 \text { mile }\end{array}$ & $\begin{array}{l}\$ 14,100 \\
\$ 36,100\end{array}$ \\
\hline $\begin{array}{l}\text { Drift Fence (semi- } \\
\text { permeable) (materials } \\
+ \text { labor) }\end{array}$ & 4 ' & 3 rows & $\$ 177 / \mathrm{ft}$ & $\begin{array}{l}2.5 \text { mile } \\
6.2 \text { mile }\end{array}$ & $\begin{array}{l}\$ 32,800 \\
\$ 78,800\end{array}$ \\
\hline $\begin{array}{l}\text { Baled Wheat Straw } \\
\text { (materials + labor) }\end{array}$ & ---- & $\begin{array}{c}3 \text { rows } \\
\text { (stacked two- } \\
\text { high) }\end{array}$ & $\$ 45 /$ ton & $\begin{array}{l}2.5 \text { mile } \\
6.2 \text { mile }\end{array}$ & $\begin{array}{l}\$ 34,600 \\
\$ 83,600\end{array}$ \\
\hline
\end{tabular}

${ }^{\mathrm{a}}$ Based on total quantities of seed provided in Table 2. 


\section{References}

Hoitink. D., K. Burk, and J. Ramsdell. 2000. Hanford Site Climatological Data Summary 1999 with Historical Data. PNNL-13117, Richland, Washington.

Holy, M. 1980. Erosion and Environment. Pergamon Press, New York. 


\section{APPENDIX}

\section{RESEEDING RECOMMENDATIONS}

Note: These recommendation were developed prior to learning that the area in question was already being replanted. These are included for future reference.

Drilling of the following three grasses is recommended to maximize soil stabilization; Siberian wheatgrass (Agropyron sibericum var. Vavilov), thickspike wheatgrass (Agropyron dasystachium var. Schwendimar), and Sherman big bluegrass (Poa secunda). These three species are recommended as being superior over crested wheatgrass (Agropyron cristatum) (\$1.50-2.00/lb [for price comparison with seed of the above grass species, see Table 2) (commonly used on the Hanford Site for interim stabilization of soils overlaying waste disposal sites, pipelines, etc.), as they are more aggressive and will persist longer on sandy soils, whereas the latter is better adapted to silt and clay loam soils. However, if crested wheatgrass were to be used, the variety Nordan is recommended, as it is reputed to be the most drought resistant (Stannard M. pers. comm. National Resource Conservation Service, Plant Materials Center [Pullman, Washinton]).

Normal seeding rates for a mixture of Siberian wheatgrass, thickspike wheatgrass, and Sherman big bluegrass would be 5, 5, 2 pounds per acre, respectively. However, due to the harsh growing conditions on the site, it may be advisable to double the seeding rate to $10,10,4$, in order to maximize the possibility of establishing a stand of grass sufficient to stabilize soils (Stannard M. pers. comm. National Resource Conservation Service, Plant Materials Center [Pullman, Washinton]).

Siberian wheatgrass, thickspike wheatgrass, and Sherman big bluegrass seed are normally drilled to a depth of $1 / 4$ "-3/8". Because of the potential for blowing sand and dust from beyond the seeded area to cover drilled seed (see following section on use of drift fences) and thereby reduce germination and establishment, seeding Indian ricegrass (Oryzopsis hymenoides var. Nezpar) may be advisable. Indian ricegrass is capable of germination and establishment at greater depths, and is thus normally drilled at from 1.5"-2.0". However, most Indian ricegrass would likely not germinate until spring of CY 2002.

Germination and establishment of all the above grasses occurs slowly, and would thus provide relatively little soil stabilization during the summer and fall of CY 2001. Consequently, grass seed would be drilled with a cover crop of triticale (hybrid of wheat and rye) (spring variety). Triticale will germinate and become established quickly (several weeks) and will thus stabilize soils during the first growing season while grasses are becoming established and offset the gradual decline in the efficacy of Soil Sement. Triticale will produce a flower head bearing sterile seeds and will die back in the fall with the cessation of irrigation. Triticale seeded at this rate will likely not put grasses at a competitive disadvantage, as long as sufficient irrigation (see below) is sustained.

Seed costs per pound and per acre for the two seeding rates of Siberian wheatgrass, thickspike wheatgrass, Sherman big bluegrass, Indian ricegrass, and triticale are provided in Table A-1. 
The cost of shipping the total quantity of seed (multiply total quantity of seed per acre in Table A-1 by 50 acres), regardless of seed mix, from $L \& H$ Seed (Connell, Washington) to the Hanford Site would be $\sim \$ 150$.

Table A-1. Seed costs.

\begin{tabular}{|l|c|c|c|c|c|}
\hline \hline Species & $\begin{array}{c}\text { Price (\$)/lb } \\
\text { PLS }^{\mathrm{a}}\end{array}$ & $\begin{array}{c}\text { Seeding } \\
\text { Rate } \\
(\mathrm{lbs} / \text { acre) }\end{array}$ & $\begin{array}{c}\text { Price(\$)/acre } \\
\text { PLS }\end{array}$ & $\begin{array}{c}\text { Seeding } \\
\text { Rate } \\
(1 \mathrm{bs} / \text { acre })\end{array}$ & $\begin{array}{c}\text { Price(\$)/acre } \\
\text { PLS }\end{array}$ \\
\hline $\begin{array}{l}\text { Siberian } \\
\text { wheatgrass }\end{array}$ & $2.00-2.50$ & 5 & $10-12.50$ & 10 & $20-25$ \\
\hline $\begin{array}{l}\text { Thickspike } \\
\text { wheatgrass }\end{array}$ & $5.00-6.00$ & 5 & $25-30$ & 10 & $50-60$ \\
\hline $\begin{array}{l}\text { Sherman big } \\
\text { bluegrass }\end{array}$ & $3.00-3.50$ & 2 & $6-7.00$ & 4 & $12-14$ \\
\hline $\begin{array}{l}\text { Indian } \\
\text { ricegrass }\end{array}$ & $24.00-25.00$ & 3 & $72-75$ & same $^{\mathrm{b}}$ & same $^{\mathrm{b}}$ \\
\hline Triticale & $0.27-0.32$ & $20-30$ & $5.40^{\mathrm{c}}-9.60^{\mathrm{d}}$ & same $^{\mathrm{b}}$ & same $^{\mathrm{b}}$ \\
\hline Total & $35-45$ & $118.40^{\mathrm{c}}-$ & $47-57$ & $159.40^{\mathrm{c}}-$ \\
$134.10^{\mathrm{d}}$ & & $183.60^{\mathrm{d}}$ \\
\hline
\end{tabular}

${ }^{\text {a }}$ Viable seed without impurities

${ }^{\mathrm{b}}$ Seeding rates and hence associated costs are constant for Indian ricegrass and triticale

${ }^{\mathrm{c}}$ based on seeding triticale at $\$ 0.27 / \mathrm{lb}$ at $20 \mathrm{lbs} /$ acre

${ }^{\mathrm{d}}$ based on seeding triticale at $\$ 0.32 / \mathrm{lb}$ at $30 \mathrm{lbs} /$ acre

Grass seed and triticale may be seeded simultaneously with a drill capable of seeding at different depths. Seeding may be done with a Birllion drill that randomly drops seeds rather than drilling in rows. This will achieve denser grass stands and consequently more homogeneous soil stabilization. Due to the potential for wind transport of drilled seed, the maximum area that should be drilled per day should not exceed that to which Soil Sement, mulch, and fertilizer can be applied in a single day, i.e., 8-10 acres. The drill and one operator would cost $\sim \$ 150 /$ acre. The total per acre costs for the seed, drill, and operator would range from $\sim \$ 250$ /acre to $\sim \$ 350$ /acre (using the total seed costs from Table 2). 